\title{
ANALISIS POLA PIKIR DAN PERILAKU LINGKUNGAN MAHASISWA PROGRAM STUDI PENDIDIKAN FISIKA FKIP UNRI TERHADAP LINGKUNGAN HIDUP DI KAMPUS FKIP UNRI
}

\author{
Muhammad Syafi'i \\ Dosen Program Studi Pendidikan Fisika. FKIP Universitas Riau, Pekanbaru \\ forsyafii@gmail.com
}

\begin{abstract}
ABSTRAK. Penelitian ini bertujuan untuk: (i) untuk menentukan sejauh mana pola pikir dan perilaku lingkungan mahasiswa Program Studi Pendidikan Fisika FKIP Unri terhadap lingkungan hidup di Fakultas Keguruan dan Ilmu Pendidikan (FKIP) Universitas Riau; (ii) untuk menguji / menganalisis apakah ada hubungan antara jenis kelamin, pola pikir dan perilaku peduli lingkungan. Dari hasil penelitian yang diperoleh bahwa pola pikir dan perilaku mahasiswa Pendidikan Fisika terhadap kepedulian lingkungan hidup di Kampus FKIP UNRI, sebagai berikut: (i) mayoritas responden atau 50-58\% dari responden memiliki skor yang baik tentang pola pikir lingkungan; (ii) ada 53\%-65\% dari responden menyadari bahwa responden salah dalam menjaga kualitas lingkungan di kampus FKIP Universitas Riau ; (iii) kesadaran lingkungan masih rendah, terbukti dari jawaban responden, di mana jawabannya jarang terlibat (JT) adalah jawaban tebanyak, terbukti dengan jumlah skor (40-53\%). Dari hasil pengujian hubungan antara variabel jenis kelamin, dengan pola pikir dan perilaku mahasiswa prodi pendidikan fisika FKIP Unri terhadap lingkungan di kampus FKIP Unri diperoleh kesimpulan bahwa: (i) Jenis Kelamin tidak berhubungan dengan pola pikir dan perilaku tentang lingkungan , jenis kelamin tidak juga berhubungan dengan kepedulian terhadap kualitas lingkungan Kampus FKIP Unri ; (ii) pola pikir berkaitan dengan perilaku mahasiswa Program Studi Pendidikan Fisika FKIP Unri, pola pikir juga terkait dengan kepedulian terhadap menjaga kualitas lingkungan.
\end{abstract}

Kata kunci: Pola Pikir, Perilaku, Mahasiswa Fisika FKIP UNRI, Kualitas Lingkungan.

\section{ANALYSIS OF THOUGHTS AND ENVIRONMENTAL BEHAVIOR STUDENTS OF PHYSICS EDUCATION, FKIP UNRI ON THE ENVIRONMENT IN THE CAMPUS OF FKIP UNRI}

\begin{abstract}
This study aims to: (i) to determine the extent of mindset and environmental behavior students Physics Education Study Program FKIP towards the environment in the Riau University Teaching and Education Faculty (FKIP); (ii) to test / analyze whether there is a relationship between gender, mindset and environmental care behavior Physics Education students at the FKIP UNRI Campus. From the results of the study, it was found that the mindset and behavior Physics Education students towards environmental concerns in FKIP UNRI Campus, as follows: (i) the majority of respondents or 50-58\% of respondents had a good score about environmental mindset; (ii) there are $53 \%-65 \%$ of respondents aware that respondents are wrong in maintaining the quality of the environment (iii) environmental awareness is still low, as evidenced by the respondents' answers, where the answer is rarely involved (JT) is the most
\end{abstract}


common answer, as evidenced by the number of scores (40-53\%). From the results of testing the relationship between sex variables, with the mindset and behavior of students of physical education study program FKIP Unri towards the environment at the Unri FKIP campus, it was concluded that: (i) Gender is not related to mindset and behavior about the environment, sex is not also related with concern for the quality of the FKIP Unri Campus environment; (ii) mindset related to the behavior of students of the Faculty Physical Education FKIP Unri, the mindset is also related to concern for maintaining environmental quality.

Keywords: Mindset, Behavior, Students Physics FKIP UNRI, Environmental Quality, FKIP UNRI Campus

\section{PENDAHULUAN}

Krisis lingkungan hidup global yang kita alami dewasa ini telah meluas menjadi permasalahan yang fundamental, segala bentuk masalah lingkungan hidup yang dihadapi saat ini di dunia maupun di Indonesia lebih banyak disebabkan oleh kesalahan fundamental-filosofis dalam pemahaman dan cara pandang manusia mengenai dirinya. Salah satu masalah yang dihadapi di Provinsi Riau adalah maslah pengelolaan lingkungan hidup. Sejauh ini terdengar upaya yang dilakukan oleh pemerintah setempat untuk mengupayakan pengelolaan lingkungan hidup. Namun sejauh ini pula lingkungan hidup tetap menjadi masalah utama. Proses pembangunan pengetahuan tentang lingkungan juga terjadi di Perguruan Tinggi di Provinsi Riau, Seperti Universitas Riau (UR) sebagai peruruan tinggi negeri di Provinsi Riau, salah satu fakultas yang ada di UR adalah Fakultas Keguruan dan Ilmu Pendidikan (FKIP) Universitas Riau. FKIP UR diharapkan mampu menciptakan guru sebagai tenaga pendidik yang. profesional terhadap bidangnya dan juga menjadi pioner peduli terhadap lingkungan. Namun sejauh ini masalah lingkungan hidup masih terjadi di kampus FKIP UR.
Mahasiswa masih kurang nyaman untuk melakukan perkuliahan dikarenakan masih banyaknya sampah yang berserakan baik didalam kelas maupun di pekarangan kampus, adanya polusi terhadap pencemaran udara di kampus, serta masalah drainase dan wc yang tidak bersih masih menjadi kendala besar di kampus FKIP UR. Sementara di FKIP UR telah memberikan stimulan terhadap mahasiswa mengenai lungkungan hidup dengan cara memberikan mata kuliah pendidikan lingkungan pada kurikulum di FKIP UR. Setiap mahasiswa di setiap program studi wajib mendapatkan mata kuliah pendidikan lingkungan sebanyak 2 SKS sebagai wujud kebijakan FKIP UR untuk menciptakan calon guru yang peduli dengan lingkungan. Termasuk Program Studi Pendidikan Fisika yang merupakan salah satu program studi yang ada di FKIP UR.

Program Studi Pendidikan Fisika FKIP UR di Provinsi Riau cukup berkembang, berdiri pada tahun 1994 dengan jumlah mahasiswa yang aktif pada tahun akademik 2016-2017 berjumlah 283 orang dengan jumlah mahasiswa sebanyak 42 orang dan mahasiswi sebanyak 241 orang. Jumlah tersebut memberikan kontribusi yang besar pada sektor akademik maupun non akademik di FKIP UR, termasuk berkontribusi terhadap 
masalah dan pengelolaan lingkungan di kampus FKIP UR. Mata kuliah pendidikan lingkungan wajib diambil mahasiswa pada semester 3 (tiga) tahun kedua pada kurikulum program studi pendidikan fisika FKIP UR.

Sejalan dengan hal diatas, hasil Asari (2001) mengungkapkan bahwa siswa pramuka memiliki pengetahuan dan sikap kepedulian yang tinggi terhadap lingkungan hidup. Hal ini disebabkan oleh kurikulum dalam latihan kepramukaan. Pengetahuan lingkungan siswa yang mengikuti kegiatan kepramukaan (siswa pramuka) diperoleh melalui : (i) pengalaman nyata dalam kegiatan kepramukaan yang dilakukan di lingkungan alam; (ii) pencapaian Syarat Kecakapan Umum (SKU) yang menambah wawasan lingkungan hidup; (iii) pencapaian Syarat Kecakapan Khusus (SKK) dala bidang lingkungan hidup; dan (iv) kegiatan kepramukaan seperi Lomba Tingkat (LT). Jambore, Perkemahan, dan lain-lain.

Permasalahan lingkngan hidup merupakan masalah yang sangat komplek yang harus segera diatasi, salah satunya adalah, pencemaran air, pencemaran udara, limbah sampah, dan banyak lagi hal lain yang terjadi di kampus FKIP UR. Semuanya membutuhkan upaya-upaya sadar dari civitas akademika FKIP UR terutama mahasiswa dan mahasiswi yang peduli untuk dapat membantu pemecahan masalah tersebut, untuk itu pulalah penelitian ini dilakukan dan mencoba untuk merumuskan permasalahan dalam bentuk pertanyaan pe-nelitian : (i). Bagaimana pola pikir dan perilaku lingkungan mahasiswa Program Studi Pendidikan Fisika FKIP Unri terhadap lingkungan hidup di Fakultas Keguruan dan Ilmu Pendidikan (FKIP) Universitas Riau; (ii). Apakah ada hubungan antara jenis kelamin, pola pikir dan perilaku peduli lingkungan mahasiswa Pendidikan Fisika di Kampus FKIP UNRI

Tujuan penelitian ini adalah : (i) untuk menentukan sejauh mana pola pikir dan perilaku lingkungan mahasiswa Program Studi Pendidikan Fisika FKIP Unri terhadap lingkungan hidup di Fakultas Keguruan dan Ilmu Pendidikan (FKIP) Universitas Riau ; (ii) untuk menguji / menganalisis apakah ada hubungan antara jenis kelamin, pola pikir dan perilaku peduli lingkungan mahasiswa Pendidikan Fisika di Kampus FKIP UNRI

Hipotesis dalam penelitian ini adalah : terdapat hubungan diantara variabel jenis kelamin, pola pikir, perilaku dan kepedulian terhadap lingkungan hidup. Populasi adalah mahasiswa yang aktif program studi Pendidikan Fisika FKIP UR, yang sudah mengambil mata kuliah pendidikan lingkungan. Penelitian ini mencoba untuk melihat hubungan antara variabel pola pikir dan perila$\mathrm{ku}$ dengan variabel jenis kelamin mahasiswa/wi Program Studi Pendidkan Fisika FKIP UR.

\section{TINJAUAN PUSTAKA. Pola Pikir}

Pola pikir adalah pola-pola dominan yang menjadi acuan utama seseorang untuk bertindak. Pola yang menetap dalam pikiran bawah sadar seseorang. Pengalaman yang direkam dalam pikiran bawah sadar membentuk pola pikir. Pengalaman yang di-miliki seseorang dapat bersifat positif maupun negatif. Tanpa disadari lingku-ngan sekitar 
kita dapat membentuk pola pikir negatif yang dapat merusak diri sendiri.

Pola pikir akan terbentuk melalui " IMPRINT “ yaitu proses pembiasaan diri atau pengalaman yang direkam sejak masa kecil pada seseorang. Sedangkan imprinting adalah suatu proses reaksi tingkah laku yang diperoleh orang selama masih sangat muda dalam kehidupan. Ada dua jenis pola pikir ( mindset), yaitu :

1. Pola Pikir Tetap ( fixed mindset), yaitu pola pikir yang tidak dapat ditingkatkan. Ini adalah pola pikir yang negatif, pesimis, tidak percaya diri, puas dengan keadaan yg sekarang.

2. Pola Pikir Berkembang (growth mindset ), yaitu pola pikir (pandangan) yang dapat dikembangkan melalui prak-tik, pelatihan, cara/metode yang tepat. Ini adalah pola pikir yang positif dan optimis, selalu ingin berusaha, berjuang terus, percaya bahwa bisa lebih maju.

Dari dua jenis jenis pola pikir diatas, dapat ditarik kesimpulan bahwa intinya adalah agar kita sadar bahwa pola pikir manusia itu bisa dirubah dan dikembangkan, oleh karena itu terus kembangkan kemampuan dan potensi diri Anda untuk lebih baik dan sukses. Tidak perlu menyem-bunyikan kekurangan atau kegagalan Anda, tapi carilah jalan keluarnya. Anda mem-punyai peluang berkembang secara tidak terbatas, tergantung pada usaha, perjuangan dan doa Anda. "Penemuan terbesar dari generasi kita adalah bahwa manusia dapat mengubah kehidupan mereka dengan mengubah cara berpikir mereka (William James )".

Pola pikir pelajar dapat berubah dan di rubah. Merubah pola pikir/mindset sese- orang hendaknya dengan cara lebih dahulu merubah kepercayaan atau keyakinannya ( belief). Menurut Bill Gould Pakar Transformational Thingking bahwa manusia terdiri atas 3 sistem :

1.Sistem Perilaku ( behavior system )

Sistem Prilaku / Behavior System adalah cara kita berinteraksi dengan dunia luar, juga interaksi kita dengan realitas sebagaimana kita mengerti realitas itu. Prilaku mempengaruhi pengalaman dan seba-liknya, kemudian pengalaman mempengaruhi sistem berpikir kita. Itulah sebabnya apabila ada usaha seseorng utk merubah sistem prilaku kita, biasanya kita akan menolak \& marah.

\section{Sistem Berpikir ( Thingking system )}

Sistem Berpikir ( Thingking System ) berlaku sebagai filter dua arah yang menerjemahkan berbagai kejadian atau pengalaman yang kita alami menjadi suatu kepercayaan. Selanjutnya kepercayaan ini akan mempengaruhi tindakan kita, sehingga menciptakan realitas bagi diri kita. Dengan mempelajari ketrampilan berpikir yang baru, kita dapat merubah sistem kepercayaan dan sistem prilaku kita.

3.Sistem Kepercayaan ( Belief system ).

Sistem Kepercayaan atau Belief System adalah inti dari segala sesuatu yg kita yakini sebagai realitas, kebenaran, nilai hidup dan segala sesuatu yang kita tahu mengenai dunia ini. Merubah kepercayaan (belief) merupakan hal yang sangat sulit. Be-lief ( kepercayaan) adalah sesuatu yang kita yakini benar, sehingga begitu kita meyakini sesuatu sebagai hal yang benar, maka kita akan sulit mengubah keyakinan kita itu

Tahapan dari pola pikir selanjutnya adalah pola sikap atau tingkah laku yang 
merupakan cara atau upaya yang dilakukan seseorang untuk melaksanakan pola pikir yang diyakininya. Dari pola sikap yang tergambar secara sosial dan individu itulah kita bisa melakukan analisa bagaimana pola pikir seseorang. Perilaku atau akhlak merupakan tingkah laku atau tanggapan seorang terhadap lingkungan, sifat-sifaat kejiawaan,akhlak atau budi pekerti yang menjadi ciri khas seorang. secara etimologi akhlak berasal dari kata khalaqa yang berarti mencipta, membuat, atau menjadi-kan. Akhlak adalah kata yang berbentuk mufrad, jamaknya adalahkhuluqun, yang berarti tabiat, adat atau khalakun yang berarti kejadian, buatan, ciptaan. Jadi akhlak (pe-rilaku) adalah tabiat atau sistem perilaku yang dibuat manusia, bisa baik atau buruk ter-gantung kepada tata nilai yang dipakai seba-gai landasan. Sedangkan menurut Notoat-modjo (2003) dalam Skinner me-rumuskan bahwa "perilaku merupakan respon atau reaksi seseorang terhadap stimulus atau rangsangan dari luar". Oleh karena perilaku ini terjadi melalui proses adanya stimulus terhadap organisme, dan kemudian organisme tersebut merespons, maka teori Skinner ini disebut teori "S-O-R" atau StimulusOrganisme-Respon.

\section{Perilaku}

Menurut Edward C. Tolman ( dalam Bonnes, M \& G. Secchiaroli 1995), bahwa perilaku adalah sesuatu yang secara tegas mendasari fisik dan detil fisiologis, dalam kaitan dengan proses penerimaan rangsangan, proses konduktor dan proses efektor dalam diri manusia. Menurut Baker dalam buku Sarwono W (1992) bahwa tingkah laku tidak hanya ditentukan oleh lingkungan dan sebaliknya, melainkan kedua hal itu saling menentukan dan tidak dapat dipisahkan. Menurut Baker dalam buku Environmental Psychology, A Physico-sosial introduction (Bonnes, M \& G Secchiroli 1995), bahwa pengaturan perilaku ini sebagai gejala perilaku lingkungan, yang dibatasi oleh pola aktifitas manusia dan bukan manusia dengan sistem kekuatan yang terpadu dan terkendali yang memelihara aktifitas mereka pada kondisi seimbang. Berdasarkan teori bahwa manusia masih mempunyai kecenderungan untuk selalu mengerti lingkungan dimana ini merupakan salah satu ciri utama manusia sebagai makhluk berakal sehat (S. Kaplan dalam Sarwono 1992)

\section{Lingkungan Hidup}

Lingkungan hidup adalah kesatuan ruang dengan semua benda, daya, keadaan dan makhluk hidup, termasuk didalamnya manusia dan perlakunya, yang mempengaruhi kelangsungan perikehidupan dan kesejahte-raan manusia serta makhluk hidup lainnya (UU. No. 23/ 1997). Lingkungan hidup sebagai suatu sistem yang terdiri dari 3 sub-sistem, yaitu: Lingkungan alam (ecosystem), lingkungan social (Sociosystem), dan lingkungan buatan (technosystem) dimana ketiga sub sistem ini saling berinteraksi (saling mempengaruhi) satu dan lainnya dalam membentuk suatu ketahanan. Ketahanan masing-masing subsistem ini akan mempengaruhi kondisi seimbang okosistem dan ketahanan lingkungan hidup secara keseluruhan. Dimana kondisi ini akan memberikan jaminan suatu yang ber-kelanjutan yang 
tentunya akan memberikan peningkatan kualitas hidup setiap makhluk hidup didalamnya. Lingkungan Alam (Ecosystem)

Ekosistem merupakan sistem mesin produksi di planet bumi (ecosphere) ini, menyediakan bagi kita segala macam kebutuhan kehidupan manusia, seperti air untuk diminum, makanan untuk kita makan, serat untuk pakaian, dan lain-lain. Manusia tergantung pada keberlanjutan suatu ekosistem yang sehat. Apabila kesehatan ekosistem terganggu, maka akan mengganggu kehidupan manusia. Ekosistem merupakan tatanan kesatuan secara utuh menyeluruh antara segenap unsur lingkungan hidup yang saling mempengaruhi.

\section{Lingkungan Sosial (Sociosystem)}

Manusia adalah makhluk sosial dan menurut F.E Darling dalam bukunya Social Behavior dan Survival (1952) bahwa provisi teritorial lebih memenuhi kebutuhan psikologis daripada fisiologis dan kebutuhan ini dipenuhi dalam 3 faktor, yaitu keamanan, perangsang, dan identitas diantara 3 faktor ini, identitas adalah yang terkuat kemudian stimulasi dan sekuriti, yang seringkali dikorbankan untuk mengejar 2 faktor lainnya. Motivasi manusia lebih kearah sosial dari pada biologis, selanjutnya menurutnya bahwa motivasi utama manusia ini adalah untuk mengejar superioritas dan motivasi-motivasi lainnya adalah ekspresi dari tujuan tersebut, yaitu tujuan manusia untuk menyempurnakan dirinya dan berkompensasi untuk menutupi kekurangan dan inferioritasnya. Hubungan manusia dengan manusia (interaksi antar manusia) dan hubungan manusia dengan alamnya yang terjadi didalam satu kesatuan ruang. Didalam interaksi sosial ini dipengaruhi oleh beberapa aspek sosial, yaitu tingkah laku manusia apabila berhadapan dengan sesamanya. Interaksi antar manusia dapat berlangsung dalam hal hubungan antara manusia induvidu dengan manusia induvidu lainnya, manusia induvidu dengan kelompok atau masyarakat, kelompok manusia dengan kelompok ma-nusia lainnya. Interaksi sosial ini pula bergantung pada karakteristik masing-masing pihak, karekteristik relasi antara kedua pihak itu, dan situasi dan konteks, dimana interaksi itu berlangsung. Pada saat ini terjadi interaksi antara dua pihak berlangsung pula "pertukaran hal-hal tertentu “. Rasa puas atau kurang puas dengan hasil suatu interaksi sosial yang diantaranya tergantung juga dari "hasil pertukaran" tersebut. Yang dipertukarkan adalah " resources" (sesuatu yang dapat diberikan oleh satu orang kepada orang lain).

\section{Lingkungan Buatan (Technosystem)}

Lingkungan buatan atau dikenal dengan lingkungan binaan atau lingkungan fisik, yaitu lingkungan yang dibuat oleh manusia dan tidak secara alami terbentuk. Lingkungan perkotaan dan lingkungan perdesaan adalah contoh lingkungan buatan atau lingkungan binaan. Ekspresi lingkungan fisik akan mengakibatkan dampak bagi lingkungan sosial merupakan argumen kuat didukung dengan pandangan Amos Rapoport (1980) tentang tiga pengaruh lingkungan fisik bagi manusia, yaitu :

1. Environmental determinism, dimana lisngkungan fisik mempengaruhi persepsi dan tingkah laku manusia, contohnya bila halaman rumah dipagar 
setinggi 3 meter, orang tidak bisa melihat keluar dan kedalam halaman tersebut, namun bila pagar tersebut dibuat 1,5 meter, maka akan terjadi kontak antara orang luar dan di dlam halaman pagar.

2. Environmental possibilism, dimana lingkungan fisik mungkin dapat memberikan kesempatan / hambatan - hamabatan terhadap tingkah laku manusia. Contohnya, bila membuat kompleks permukiman yang tidak memiliki fasilitas umum seperti taman bermain anak-anak, dapat menghambat kreatifitas anak-anak, atau bahkan sebaliknya taman rekreasi memberikan kesempatan bagi anak-anak untuk bermain dan berkreatifitas.

3. Environmental probabilism, dimana lingkungan fisik memberikan pilihanpilihan yang berlainan bagi tingkah laku manusia dan bahwa ada beberapa pilihan yang mungkin terjadi dari pada pilihan lainnya. Contoh, jika orang membuat halaman rumah, barangkali akan digunakan sebagai tempat menjemur pakaian, tempat bermain atau tempat menumpuk barang rongsokan.

Kualitas Lingkungan Hidup

Dimaksud dengan kualitas lingkungan hidup adalah derajat kemampuan lingkungan untuk memenuhi kebutuhan dasar manusia (basic needs) pada tempat dan dalam waktu tertentu. Kemampuan lingkungan ini mencangkup fisikokimiawi, estetika, budaya dan lain-lain. Tentunya kemampuankemampuan ini diwujudkan oleh masing- masing sub-sistem yang ada di dalam sistem lingkungan hidup, dimana secara keseluruhan ketiga sub-sistem ini akan memberikan "support"/ dukungan bagi ke-hidupan manusia.

Menurut Abraham H. Maslow, kebutuhan dasar manusia terdiri dari : (1) kebutuhan fisiologis, (2) kebutuhan akan jaminan keamanan; (3) kebutuhan akan hidup berkelompok; (4) kebutuhan akan suatu pengakuan atau penghargaan ; (5) kebutuhan untuk mengembagkan diri/self actualization. Kondisi tiga sub-sistem dalam lingkungan hidup yang semakin merosot kualitasnya akan memberikan dampak yang sangat membahayakan kehidupan kita manusia. Sumberdaya alam yang tidak berkualitas atau nyaris punah, suatu saat tidak lagi memberikan ketersediaan sumber pangan (makanan), papan dan sandang (pakaian) bagi manusia.

\section{Kerangka Konsep}

Jenis kelamin Penidikan Fisika FKIP Universitas Riau mempengaruhi pola pikir, dan serta kepeduliannya terhadap lingkungan hidup di kampus FKIP Universitas Riau

Gambar. 1

Kerangka Konsep

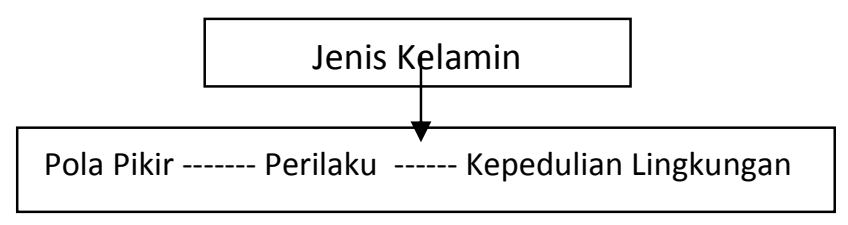

\section{METODE PENELITIAN}

Desain penelitian yang digunakan adalah survei yang bersifat korelasional, dimana tidak dilakukan perlakuan atau 
intervensi tertentu terhadap populasi sampel dan pendataan dilakukan pada satuan waktu tertentu. Penelitian dilakukan di kampus FKIP UR. Waktu penelitian dari Tanggal 6 Januari 2017 sampai dengan 5 Pebruari 2017. Populasi adalah mahasiswa Program Studi Pendidikan Fisika FKIP Universitas Riau yang sudah mengambil mata kuliah pendidikan lingkunngan.

Tabel 1

\begin{tabular}{|l|l|l|l|}
\hline \multirow{2}{*}{ Angkatan } & \multicolumn{2}{|l|}{$\begin{array}{l}\text { Jenis } \\
\text { Kelamin }\end{array}$} & \multirow{3}{*}{ Jumlah } \\
\cline { 2 - 3 } & L & P & \\
\hline 2013 & 5 & 27 & 32 \\
\hline 2014 & 14 & 36 & 50 \\
\hline 2015 & 8 & 53 & 61 \\
\hline Total & & 143 \\
\hline
\end{tabular}

Dari populasi mahasiswa tersebut diambil sampel berdasarkan perhitungan Pengambilan sampel berdasarkan Metode slovin, dengan tahapan sebagai berikut: (i) dari seluruh mahasiswa pendidikan Fisika FKIP UR diambil yang masih aktif dari berbagai angkatan yang sudah mengambil mata kuliah pendidikan lingkungan , diambil angkatan 2015, 2014 dan 2013 ; (ii) ditelusuri berapa jumlah untuk masingmasing angkatan; (iii)masing-masing angkatan diambil sampel secara random, sehingga memenuhi minimal responden yaitu sebesar 106 sampel. Besar Sampel, diperoleh dari perhitungan besar sampel berdasarkan rumus :

$$
n=\frac{N}{1+N e^{2}}
$$

dimana

$n$ : jumlah sampel

$\mathrm{N}$ : jumlah populasi

e: batas toleransi kesalahan

(error tolerance)

Data dikumpulkan dengan wawancara terarah, dengan menggunakan kuesioner yang telah disiapkan terlebih dahulu. Data yang telah diambil dilakukan melalui wawancara secara langsung pada mahasiswa yang terpilih sebagai responden. Penilaian lingkungan dilakukan, berdasarkan hasil analisis hubungan yang dilakukan pada variabel, jenis kelamin dengan pola pikir dan perilaku peduli lingkungan.

Distribusi Responden menurut variabel Pola Pikir, Perilaku dan Kepedulian

Ada tiga variabel yang ditanyakan pada 106 responden, di mana masingmasing mahasiswa terhadap lingkungan hidup. Variabel yang diperkirakan terikat dan bebas di dalam penelitian ini adalah jenis kelamin dan variabel lainnya adalah, pola pikir, perilaku dan kepedulian. Hubungan diantara variabel di atas ingin dilihat terhadap lingkungan hidup. Analisis data dilakukan dengan menggunakan analisis Chi Square. Rumus sebagai berikut: 


$$
\chi^{2}=\frac{N\left(|A D-B C|-\frac{N}{2}\right)^{2}}{(A+B)(C+D)(A+C)(B+D)}
$$

$$
\begin{aligned}
\mathrm{N}= & \text { Jumlah sampel } \\
\mathrm{A}= & \text { Kelompok sampel mahasiswa dengan } \\
& \text { kategori positif } \\
\mathrm{B}= & \text { Kelompok sampel mahasiswa dengan } \\
& \text { kategori negatif } \\
\mathrm{C}= & \text { Kelompok sampel mahsiswa yang } \\
& \text { katergori negatif untuk variabel yang } \\
& \text { diteliti } \\
\mathrm{D}= & \text { Kelompok sampel mahasiswa dengan } \\
& \text { kategori positif untuk variabel yang } \\
& \text { diteliti }
\end{aligned}
$$

\section{HASIL DAN PEMBAHASAN Karakteristik Responden}

Dari perhitungan sampel, terpilih 126 responden sebagai sampel dalam penelitian ini (tabel 2).

Tabel 2. Distribusi Responden Berdasarkan Jenis Kelamin

\begin{tabular}{|l|l|l|l|}
\hline Angkatan & \multicolumn{2}{|l|}{ Jenis } & \multirow{2}{*}{ Jumlah } \\
& \multicolumn{2}{|l|}{ Kelamin } & \\
\cline { 2 - 3 } & L & $\mathbf{P}$ & \\
\hline 2013 & 5 & 21 & 26 \\
\hline 2014 & 14 & 16 & 30 \\
\hline 2015 & 8 & 42 & 50 \\
\hline Total & $\begin{array}{l}106 \\
(100 \%)\end{array}$ \\
\hline
\end{tabular}

Responden telah menjawab sesuai pengetahuan, sikap dan kepedulian mereka yang berkaitan dengan pengelolaan lingkungan hidup di kampus FKIP UR .
Distribusi masing-masing responden berdasarkan 3 variabel tersebut, sebagai berikut:

\section{Variabel Pola Pikir}

Dari 106 orang responden distribusi yang diberikan untuk variabel pola pikir dapat dilihat bahwa untuk pertanyaan pertama tentang cara membuang sampah yang benar sebagian besar responden sudah memiliki pola pikir yang benar karena 68 orang atau 64\% memberikan jawaban yang benar yaitu memasukkan sampah ke dalam plastik, kemudian memisahkan organik dan unorganik, dan membuangnya ditempat pembuangan sampah sementara. Sementara 19 orang atau $18 \%$ responden menjawab memasukkan sampah plastik, kemudian membuangnya ke tempat sampah yang telah disediakan, 18 orang atau $17 \%$ menjawab membuang sampah ditempat yang disediakan, dan 1 orang sisanya mahasiswa menjawab membuang sampah di jalanan (tabel 1). Tidak ada satupun responden yang menjawab tidak tahu cara membuang sampah yang benar. Dari jawaban yang diberikan oleh responden, sebenarnya tampak bahwa pola pikir mahasiswa sudah terbangun dengan baik tentang cara pembuangan sampah yang benar sudah dimiliki oleh sebagian besar responden. 
Pencemaran udara di lingkungan kampus FKIP Universitas Riau belum dirasakan atau mempunyai dampak yang tidak baik kepada civitas akademika. Hal ini terbukti dari 91 orang atau $85,7 \%$ responden memilih jawaban tersebut, sementara 9 orang mahasiswa atau 8,5\% responden menjawab hanya mempengaruhi pada mahasiswa yang merokok saja. 4 orang mahasiswa mengatakan pencemaran udara mempengaruhi seluruh civitas akademika. Dan masing-masing 1 orang responden mengatakan tidak tahu dan pencemaran udara hanya mempengaruhi sebagian mahasiswa saja. Dari jawaban diatas tampak bahwa membangun pola pikir terhadap dampak pencemaran udara sudah terjaga dan sangat baik. (tabel 4).

Tabel 3. Pertanyaan 2 Apakah pencemaran udara sudah berpengaruh kepada civitas akademika FKIP Universitas Riau

\begin{tabular}{|l|l|l|l|}
\hline No & Pertanyaan & $\mathbf{n}$ & $\mathbf{\%}$ \\
\hline 1 & Tidak Tahu & 1 & 1 \\
\hline 2 & Belum mahasiswa & 91 & 85,7 \\
\hline 3 & $\begin{array}{l}\text { Mempengaruhi } \\
\text { sebagian } \\
\text { saja }\end{array}$ & 1 & 1 \\
\hline 4 & $\begin{array}{l}\text { Mempengaruhi } \\
\text { mahasiswa } \\
\text { merokok saja }\end{array}$ & 9 & 8,5 \\
\hline 5 & $\begin{array}{l}\text { Mempengaruhi seluruh } \\
\text { civitas akademika }\end{array}$ & 4 & 3,8 \\
\hline JUMLAH & 106 & 100 \\
\hline
\end{tabular}

Berbagai pandangan diberikan oleh para responden khususnya tentang kemampuan

\begin{tabular}{|c|c|c|c|}
\hline $\mathbf{N}$ & Pertanyaan & $\mathbf{n}$ & $\%$ \\
\hline 1 & Tidak Tahu & - & - \\
\hline 2 & $\begin{array}{l}\text { Membuang sampah } \\
\text { dijalanan }\end{array}$ & 1 & 1 \\
\hline 3 & $\begin{array}{l}\text { Membuang sampah di } \\
\text { tempat sampah yang } \\
\text { telah ada }\end{array}$ & 18 & 17 \\
\hline 4 & $\begin{array}{l}\text { Memasukan sampah ke } \\
\text { plastik kemudian } \\
\text { membuah ke tempat } \\
\text { yang telah disediakan }\end{array}$ & 19 & 18 \\
\hline 5 & $\begin{array}{l}\text { Memisahkan sampah } \\
\text { organik dan anorganik } \\
\text { lalu dimasukkan ke } \\
\text { plastik, membuang ke } \\
\text { tempat sampah }\end{array}$ & 68 & 64 \\
\hline \multicolumn{2}{|c|}{ JUMLAH } & 106 & 100 \\
\hline
\end{tabular}

ruang terbuka hijau mengatasi pencemaran. 60 oarang atau $56,5 \%$ responden mengatakan ada namun luasnya belum memadai. 9 orang atau 8,5\% menjawab sangat minim dan belum berfungsi, 33 orang menjawab cukup memadai dan 4 orang sisanya menjawab kurang tahu. Tidak ada satupun responden yang menjawab tidaj tahu. Dari jawaban diatas, pengetahuan para responden sudah baik karena sebagian besar dari mereka mengetahui bahwa ruang terbuka hijau sudah ada namun luasnya belum memadai karena sebagai sarana untuk mengatasi pencemaran ( tabel 5) 
Tabel 4. Pertanyaan 3 Tentang kemampuan ruang terbuka hijau mengatasi pencemaran

\begin{tabular}{|l|l|l|l|}
\hline No & Pertanyaan & n & \% \\
\hline 1 & Tidak Tahu & - & - \\
\hline 2 & Kurang tahu & 4 & 3,8 \\
\hline 3 & Cukup Memadai & 33 & 31,2 \\
\hline 4 & $\begin{array}{l}\text { Sangat Minim dan } \\
\text { belum berfungsi }\end{array}$ & 9 & 8,5 \\
\hline 5 & $\begin{array}{l}\text { Ada namun luasnya } \\
\text { belum memadai }\end{array}$ & 60 & 56,5 \\
\hline JUMLAH & 106 & 100 \\
\hline
\end{tabular}

Seperti yang kita ketahui bahwa unsur Hg yang terdapat pada limbah cair berbahaya bagi kesehatan manusia. Untuk pertanyaan ini 34 orang atau $32,1 \%$ responden menjawab benar, sementara 28 orang atau $26,4 \%$ responden mengatakan kurang tepat, tetapi oleh unsur $\mathrm{Hg}$ dan $\mathrm{Cd}$. Sebanyak 18 orang atau $17 \%$ responden menjawab salah, 15 orang atau $14,1 \%$ responden menjawab tidak tahu, dan sisanya sebanyak 11 orang atau $10,4 \%$ menjawab kurang tepat karena selain unsur $\mathrm{Hg}$ juga terdapat unsur $\mathrm{Cd}$ dan Ar. Dengan banyaknya responden menjawab dengan kurang tepat, menunjukan bahwa pola pikir responden tentang unsur yang berbahaya pada limbah cair masih perlu ditingkatkan (tabel 6).

Tabel 5. Pertanyaan 4 Tentang $\mathrm{Hg}$ adalah unsur yang berbahaya pada limbah cair

\begin{tabular}{|l|l|l|l|}
\hline No & Pertanyaan & n & \% \\
\hline 1 & Tidak Tahu & 15 & 14,1 \\
\hline 2 & Benar & 34 & 32,1 \\
\hline 3 & Salah & 18 & 17 \\
\hline 4 & Kurang tepat, tetapi $\mathrm{Hg}$ & 28 & 26,4 \\
\hline
\end{tabular}

\begin{tabular}{|l|l|l|l|}
\hline & dan Cd & & \\
\hline 5 & $\begin{array}{l}\text { Kurang Tepat, tetapi } \\
\mathrm{Hg}, \mathrm{Cd}, \text { dan Ar }\end{array}$ & 11 & 10,4 \\
\hline JUMLAH & 106 & 100 \\
\hline
\end{tabular}

Ada berbagai bentuk kebijakan kelembagaan FKIP Universitas Riau tentang pengelolaan lingkungan hidup. Untuk pertanyaan tersebut pilihan jawaban tertinggi yang diberikian responden adalah ada kebijakan tetapi tidak didukung sarana prasarana yaitu dijawab oleh 58 orang orang atau $54,7 \%$ responden, jawaban tertinggi kedua adalah ada tetapi hanya diketahui sebagian kelompok saja dijawab sebanyak 26 orang atau 24,5\%. Untuk jawaban tidak ada hanya menjawab sebanyak 4 orang atau 3,8 $\%$ dan yang menjawab belum tahu adanya kebijakan sebanyak 18 orang atau $17 \%$ dan tidak ada satupun responden yang menjawab tidak tahu. Dari jawaban yang diberikan tampak pembangunan pola pikir mahasiswa atau responden tentang masalah kebijakan sudah terbangun dalam pikiran mahasiswa.

Tabel 6 . Pertanyaan 5 Kebijakan kelembagaan FKIP Universitas Riau tentang pengelolaan lingkungan hidup

\begin{tabular}{|l|l|l|l|}
\hline No & Pertanyaan & n & \% \\
\hline 1 & Tidak Tahu & - & - \\
\hline 2 & Belum tahu & 18 & 17 \\
\hline 3 & Tidak ada & 4 & 3,8 \\
\hline 4 & $\begin{array}{l}\text { Ada, Hanya diketahui } \\
\text { sebagian kelompok saja }\end{array}$ & 26 & 24,5 \\
\hline 5 & $\begin{array}{l}\text { Ada, tetapi tidak } \\
\text { didukung } \\
\text { Prasarana }\end{array}$ & 58 & 54,7 \\
\hline JUMLAH & $\mathbf{1 0 6}$ & $\mathbf{1 0 0}$ \\
\hline
\end{tabular}


Ada satu pertanyaan terbuka yang diberikan kepada responden yaitu mengenai fasilitas umum apa saja yang diketahui oleh responden. Sebagian besar responden bisa menyebutkan jenis atau macam fasilitas umum dengan benar yaitu lima atau lebih dari lima jenis fasilitas umum sebanyak 61 orang atau 57,5\% responden. Jawaban yang diberikan diantaranya adalah, toilet,parkir, kantin, mushola, tempat sampah dan lain sebagainya. Sedagkan 45 orang atau 42,5\% responden lainnya memberikan jawaban bervariasi dari 1 hingga 4 jenis fasilitas umum. Dari jawaban diatas tampak bahwa pola pikir responden tentang fasilitas umum yang mereka ketahui cukup baik karena sebanyak 57, $5 \%$ responden dapat memberikan jawaban yang memadai (tabel 8)

Tabel 7. Pertanyaan 6 tentang sebutkan fasilitas umum yang diketahui

\begin{tabular}{|l|l|l|l|}
\hline No & Pertanyaan & $\mathbf{n}$ & $\mathbf{\%}$ \\
\hline 1 & Satu Jenis & 20 & 18,9 \\
\hline 2 & Dua Jenis & 7 & 6,6 \\
\hline 3 & Tiga Jenis & 13 & 12,3 \\
\hline 4 & Empat Jenis & 5 & 4,7 \\
\hline 5 & Lima Jenis & 61 & 57,5 \\
\hline \multicolumn{2}{|l}{ JUMLAH } & 106 & 100 \\
\hline
\end{tabular}

\section{Variabel Perilaku}

Selain memberikan daftar pertanyaan tentang variabel pola pikir, pernyataan tentang variabel perilaku juga diajukan kepada responden yang sama dengan hasil seperti pada tabel Tabel 9. Instrumen Perilaku terhadap lingkungan hidup, dimana pernyataan tentang pencemaran udara mempengaruhi civitas kampus reponden menjawab $29 \%$ sangat tidak setuju, $1,8 \%$ responden menjawab tidak setuj, 40,6 setuju dan 54,7 sangat setuju. Lebih lanjut tentang dampak pencemaran udara hanya mem-pengaruhi sekelompok tempat saja36,8 \% responden menjawab sangat tidak setuju dengan jumlah 39 orang, 53,8 \% tidak setuju dengan jumlah 57 orang, 7,6 \% setuju, dan $1,8 \%$ sangat setuju.

Pernyataan lain yang diberikan kepada responden adalah tentang kebutuhan ruang hijau diraakan harus memadai sebanyak $1 \%$ atau 1 orang responden menjawab sangat tidak setuju, $1 \%$ juga responden menjawab tidak setuju, $45,2 \%$ atau 48 orang responden menjawab setuju dan $52,8 \%$ atau 56 orang responden menjawab sangat setuju. Lebih lanjut pertanyaan berikutnya kepada responden tentang selokan-selokan di kampus sudah mulai tercemar dan tersumbat, responden menjawab 1 orang atau $1 \%$ sangat tidak setuju, sebanyak 3,7 atau 4 orang menjawab tidak setuju, 30,2 atau 32 responden menjawab setuju dan 65,1 menjawab sangat setuju. Untuk rasa kesetiakawanan dan gotong royong antar mahasiswa sudah berkurang tidak ada yang menjawab sangat tidak setuju, $17 \%$ atau 18 responden menjawab tidak setuju, 58,5\% atau 62 orang setuju dan 24,5 sangat setuju.

Kebijakan kelembagaan dalam bidang lingkungan belum menyentuh bagian yang esensial dari lingkungan hidup responden menjawab 9 mahasiswa atau 8,5 \% tidak setuju, $65,1 \%$ atau 69 responden menjawab setuju dan 28 responden atau $26,4 \%$ sangat setuju,dan tidak ada satupun responden menjawab sangat tidak setuju. Ketersedian 
runga terbuka hijau lebih dikalahkan oleh keperluan pembangunan kampus, Persoalan sampah sudah memasuki tahap krisis, Peran serta Dosen dalam memberikan arti pentingnya menjaga lingkungan hidup masih kuran dan Peran serta mahasiswa untuk menjaga lingkungan semakin tidak diraskan dapat dilihat pada tabel 9 berikut ini :

Tabel 8. Instrumen Perilaku terhadap lingkungan hidup.

\begin{tabular}{|c|c|c|c|c|c|c|c|c|c|}
\hline \multirow{2}{*}{$\begin{array}{l}N \\
o\end{array}$} & \multirow{2}{*}{$\begin{array}{l}\text { Pernyata } \\
\text { an }\end{array}$} & \multicolumn{2}{|c|}{ STS } & \multicolumn{2}{|c|}{ TS } & \multicolumn{2}{|l|}{$\mathrm{S}$} & \multicolumn{2}{|l|}{ SS } \\
\hline & & $\mathrm{n}$ & $\%$ & $\mathrm{n}$ & $\%$ & \begin{tabular}{l|l}
$\mathrm{n}$ \\
\end{tabular} & $\%$ & $\begin{array}{ll}\mathrm{n} \\
\end{array}$ & $\%$ \\
\hline 1 & $\begin{array}{l}\text { Pencem } \\
\text { aran } \\
\text { udara } \\
\text { mempen } \\
\text { garuhi } \\
\text { civitas } \\
\text { kampus }\end{array}$ & 3 & $\begin{array}{l}2, \\
9\end{array}$ & 2 & $\begin{array}{l}1, \\
8\end{array}$ & $\begin{array}{l}4 \\
3\end{array}$ & $\begin{array}{l}4 \\
0, \\
6\end{array}$ & $\begin{array}{l}5 \\
8\end{array}$ & $\begin{array}{l}5 \\
4, \\
7\end{array}$ \\
\hline 2 & $\begin{array}{l}\text { Pencem } \\
\text { aran } \\
\text { udara } \\
\text { hanya } \\
\text { mempen } \\
\text { garuhi } \\
\text { sekelom } \\
\text { pok } \\
\text { tempat } \\
\text { saja } \\
\end{array}$ & $\begin{array}{l}3 \\
9\end{array}$ & $\begin{array}{l}3 \\
6 \\
8\end{array}$ & $\begin{array}{l}5 \\
7\end{array}$ & $\begin{array}{l}5 \\
3, \\
8\end{array}$ & 8 & $\begin{array}{l}7, \\
6\end{array}$ & 2 & $\begin{array}{l}1, \\
8\end{array}$ \\
\hline 3 & $\begin{array}{l}\text { Kebutuh } \\
\text { an ruang } \\
\text { hijau } \\
\text { dirasaka } \\
\text { n harus } \\
\text { memada } \\
\text { i }\end{array}$ & 1 & 1 & 1 & 1 & $\begin{array}{l}4 \\
8\end{array}$ & $\begin{array}{l}4 \\
5, \\
2\end{array}$ & $\begin{array}{l}5 \\
6\end{array}$ & $\begin{array}{l}5 \\
2, \\
8\end{array}$ \\
\hline 4 & $\begin{array}{l}\text { Selokan- } \\
\text { selokan }\end{array}$ & 1 & 1 & 4 & $\begin{array}{l}3, \\
7\end{array}$ & $\begin{array}{l}3 \\
2\end{array}$ & $\begin{array}{l}3 \\
0,\end{array}$ & $\begin{array}{l}6 \\
9\end{array}$ & $\begin{array}{l}6 \\
5,\end{array}$ \\
\hline
\end{tabular}

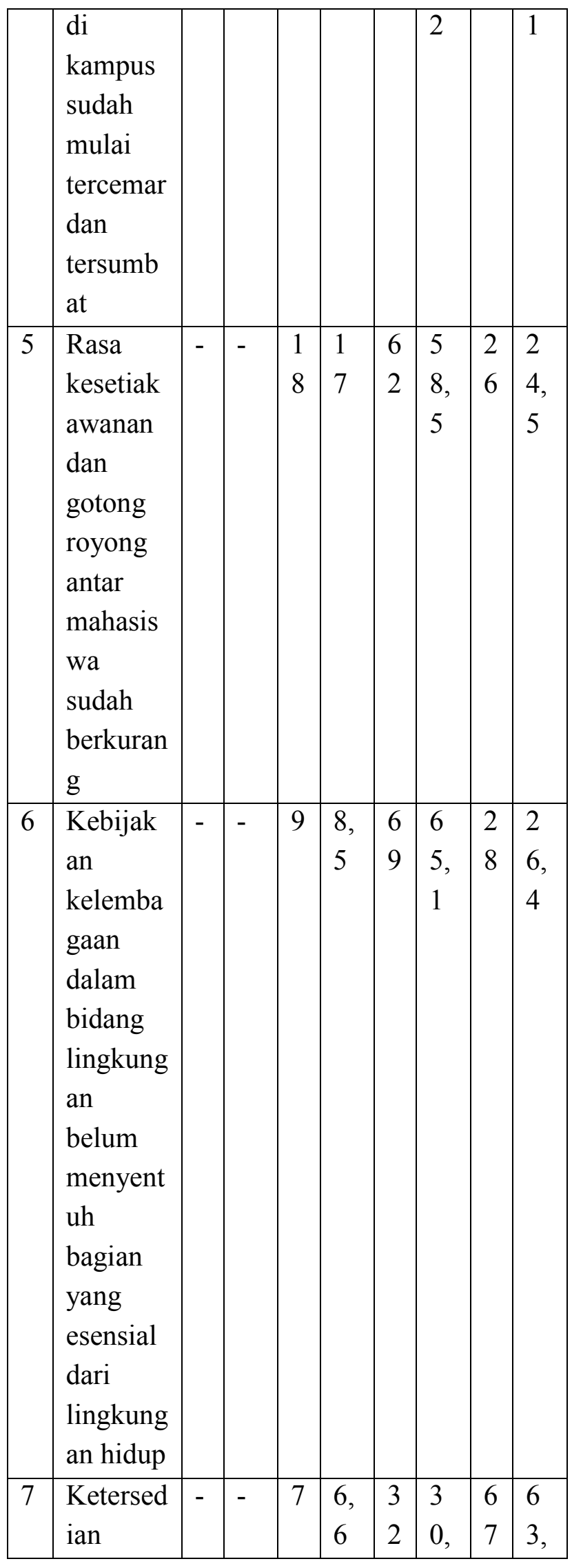




\begin{tabular}{|c|c|c|c|c|c|c|c|c|c|}
\hline & $\begin{array}{l}\text { runga } \\
\text { terbuka } \\
\text { hijau } \\
\text { lebih } \\
\text { dikalahk } \\
\text { an oleh } \\
\text { keperlua } \\
\text { n } \\
\text { pemban } \\
\text { gunan } \\
\text { kampus }\end{array}$ & & & & & & 2 & & 2 \\
\hline 8 & $\begin{array}{l}\text { Persoala } \\
\mathrm{n} \\
\text { sampah } \\
\text { sudah } \\
\text { memasu } \\
\text { ki tahap } \\
\text { krisis }\end{array}$ & 1 & 1 & 4 & $\begin{array}{l}3, \\
6\end{array}$ & $\begin{array}{l}5 \\
4\end{array}$ & $\begin{array}{l}5 \\
1, \\
8\end{array}$ & $\begin{array}{l}4 \\
7\end{array}$ & $\begin{array}{l}4 \\
4, \\
4\end{array}$ \\
\hline 9 & $\begin{array}{l}\text { Peran } \\
\text { serta } \\
\text { Dosen } \\
\text { dalam } \\
\text { memberi } \\
\text { kan arti } \\
\text { pentingn } \\
\text { ya } \\
\text { menjaga } \\
\text { lingkung } \\
\text { an hidup } \\
\text { masih } \\
\text { kurang }\end{array}$ & - & - & $\begin{array}{l}1 \\
0\end{array}$ & $\begin{array}{l}9, \\
4\end{array}$ & $\begin{array}{l}5 \\
1\end{array}$ & $\begin{array}{l}4 \\
8, \\
1\end{array}$ & $\begin{array}{l}4 \\
5\end{array}$ & $\begin{array}{l}4 \\
2, \\
5\end{array}$ \\
\hline $\begin{array}{l}1 \\
0\end{array}$ & $\begin{array}{l}\text { Peran } \\
\text { serta } \\
\text { mahasis } \\
\text { wa } \\
\text { untuk } \\
\text { menjaga } \\
\text { lingkung } \\
\text { an }\end{array}$ & 1 & 1 & $\begin{array}{l}2 \\
4\end{array}$ & $\begin{array}{l}2 \\
2, \\
6\end{array}$ & $\begin{array}{l}4 \\
5\end{array}$ & $\begin{array}{l}4 \\
2 \\
4\end{array}$ & $\begin{array}{l}3 \\
6\end{array}$ & $\begin{array}{l}3 \\
4\end{array}$ \\
\hline
\end{tabular}

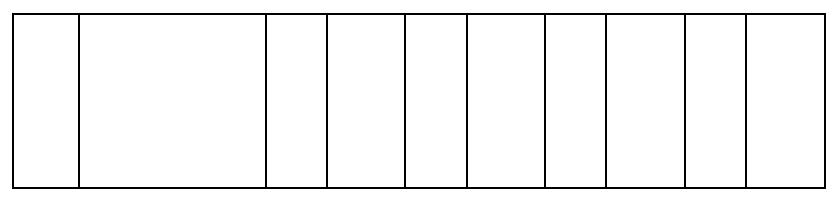

\section{Variabel Kepedulian}

Untuk mengetahui persepsi responden tentang pengelolaan lingkungan hidup, selain ditanyakan melalui variabel pola pikir dan perilaku di mana hasilnya sudah dijabarkan di atas, juga ditanyakan tentang variabel kepedulian. Jawaban yang diperoleh dari 106 responden yang sama adalah sebagai berikut:

Untuk kepedulian, Melakukan Pembakaran sampah, Merawat Kendaraan untuk mengurangi emisi, Menanam/memelihara tanaman sekitar lingkungan kampus, Menggunakan bahan-bahan plastik yang tidak ramah lingkungan, Terlibat dalam kegiatan gotong royong lingkungan kampus, Peduli pada sesama mahasiswa yang terkena penyakit, Meningkatkan kedisiplinan waktu, Ikut serta mensosialisasikan program pemerintah untuk melestarikan lingkungan, Menggunakan barang-barang yang masih bisa dimanfaatkan seperti kertas, plastik, botol dsb, Memanfaatkan dan menjaga kebersihan fasilitas umum, Mengurangi berpergian dengan kendaraan untuk tujuan yang dekat, Membuang sampah pada tempatnya dapat dilihat pada tabel 10. Tetang instrumen kepedulian terhadap lingkungan hidup.

Tabel 9. Instrumen Kepedulian terhadap lingkungan hidup.

\begin{tabular}{|l|l|l|l|l|l|l|l|l|l|}
\hline N & Pernyataa & \multicolumn{2}{|l|}{ HST } & \multicolumn{2}{l|}{ ST } & \multicolumn{2}{l|}{ JT } & \multicolumn{2}{l|}{ TPT } \\
\cline { 2 - 9 } $\mathrm{o}$ & $\mathrm{n}$ & $\mathrm{n}$ & $\%$ & $\mathrm{n}$ & $\%$ & $\mathrm{n}$ & $\%$ & $\mathrm{n}$ & $\%$ \\
\hline 1 & Melakuka & 1 & 12 & 3 & 28 & 3 & 32 & 2 & 27 \\
& $\mathrm{n}$ & 3 &, 2 & 0 &, 3 & 4 & & 9 &, 5 \\
\hline
\end{tabular}




\begin{tabular}{|c|c|c|c|c|c|c|c|c|c|}
\hline & $\begin{array}{l}\text { Pembakar } \\
\text { an sampah }\end{array}$ & & & & & & & & \\
\hline 2 & $\begin{array}{l}\text { Merawat } \\
\text { Kendaraa } \\
\mathrm{n} \quad \text { untuk } \\
\text { menguran } \\
\text { gi emisi }\end{array}$ & $\begin{array}{l}2 \\
4\end{array}$ & $\begin{array}{l}22 \\
, 7\end{array}$ & 4 & $\begin{array}{l}22 \\
, 7\end{array}$ & $\begin{array}{l}3 \\
8\end{array}$ & $\begin{array}{l}35 \\
, 7\end{array}$ & 2 & $\begin{array}{c}18 \\
9\end{array}$ \\
\hline 3 & $\begin{array}{l}\text { Menanam } \\
\text { / } \\
\text { memeliha } \\
\text { ra } \\
\text { tanaman } \\
\text { sekitar } \\
\text { lingkunga } \\
\text { n kampus }\end{array}$ & $\begin{array}{l}2 \\
2\end{array}$ & $\begin{array}{l}20 \\
, 7\end{array}$ & 3 & $\begin{array}{l}35 \\
, 8\end{array}$ & $\begin{array}{l}3 \\
7\end{array}$ & 35 & 9 & $\begin{array}{l}8, \\
5\end{array}$ \\
\hline 4 & $\begin{array}{l}\text { Menggun } \\
\text { akan } \\
\text { bahan- } \\
\text { bahan } \\
\text { plastik } \\
\text { yang tidak } \\
\text { ramah } \\
\text { lingkunga } \\
\text { n }\end{array}$ & $\begin{array}{l}1 \\
5\end{array}$ & $\begin{array}{l}14 \\
1\end{array}$ & $\begin{array}{l}3 \\
8\end{array}$ & $\begin{array}{l}35 \\
, 9\end{array}$ & $\begin{array}{l}3 \\
7\end{array}$ & $\begin{array}{l}34 \\
9\end{array}$ & 6 & $\begin{array}{l}15 \\
1\end{array}$ \\
\hline 5 & $\begin{array}{l}\text { Terlibat } \\
\text { dalam } \\
\text { kegiatan } \\
\text { gotong } \\
\text { royong } \\
\text { lingkunga } \\
\text { n kampus }\end{array}$ & $\begin{array}{l}1 \\
9\end{array}$ & $\begin{array}{l}17 \\
9\end{array}$ & $\begin{array}{l}2 \\
2\end{array}$ & $\begin{array}{l}20 \\
, 7\end{array}$ & $\begin{array}{l}5 \\
4\end{array}$ & 51 & $\begin{array}{l}1 \\
1\end{array}$ & $\begin{array}{l}10 \\
4\end{array}$ \\
\hline 6 & $\begin{array}{l}\text { Peduli } \\
\text { pada } \\
\text { sesama } \\
\text { mahasisw } \\
\text { a yang } \\
\text { terkena } \\
\text { penyakit }\end{array}$ & $\begin{array}{l}1 \\
0\end{array}$ & $\begin{array}{l}9, \\
4\end{array}$ & 6 & $\begin{array}{l}62 \\
, 3\end{array}$ & $\begin{array}{l}2 \\
6\end{array}$ & $\begin{array}{l}24 \\
, 6\end{array}$ & 4 & $\begin{array}{l}3, \\
7\end{array}$ \\
\hline 7 & $\begin{array}{l}\text { Meningka } \\
\text { tkan } \\
\text { kedisiplin } \\
\text { an waktu }\end{array}$ & 9 & $\begin{array}{l}8, \\
4\end{array}$ & $\begin{array}{l}3 \\
8\end{array}$ & $\begin{array}{l}35 \\
9\end{array}$ & $\begin{array}{l}5 \\
6\end{array}$ & $\begin{array}{c}52 \\
, 8\end{array}$ & 3 & $\begin{array}{c}32 \\
, 8\end{array}$ \\
\hline
\end{tabular}

\begin{tabular}{|c|c|c|c|c|c|c|c|c|c|}
\hline 8 & $\begin{array}{l}\text { Ikut serta } \\
\text { mensosial } \\
\text { isasikan } \\
\text { program } \\
\text { pemerinta } \\
\text { h untuk } \\
\text { melestarik } \\
\text { an } \\
\text { lingkunga } \\
\mathrm{n}\end{array}$ & 9 & $\begin{array}{l}8, \\
4\end{array}$ & $\begin{array}{l}5 \\
2\end{array}$ & 49 & $\begin{array}{l}4 \\
1\end{array}$ & $\begin{array}{l}38 \\
, 8\end{array}$ & 4 & $\begin{array}{l}3, \\
8\end{array}$ \\
\hline 9 & $\begin{array}{l}\text { Menggun } \\
\text { akan } \\
\text { barang- } \\
\text { barang } \\
\text { yang } \\
\text { masih bisa } \\
\text { dimanfaat } \\
\text { kan } \\
\text { seperti } \\
\text { kertas, } \\
\text { plastik, } \\
\text { botol dsb }\end{array}$ & $\begin{array}{l}1 \\
5\end{array}$ & $\begin{array}{l}14 \\
, 1\end{array}$ & 3 & $\begin{array}{l}40 \\
, 7\end{array}$ & $\begin{array}{l}4 \\
0\end{array}$ & $\begin{array}{l}37 \\
, 7\end{array}$ & 8 & $\begin{array}{l}7, \\
5\end{array}$ \\
\hline 0 & $\begin{array}{l}\text { Memanfa } \\
\text { atkan dan } \\
\text { menjaga } \\
\text { kebersiha } \\
\mathrm{n} \text { fasilitas } \\
\text { umum }\end{array}$ & 9 & $\begin{array}{l}8, \\
5\end{array}$ & 4 & $\begin{array}{l}37 \\
6\end{array}$ & $\begin{array}{l}3 \\
7\end{array}$ & 35 & 2 & $\begin{array}{l}8, \\
9\end{array}$ \\
\hline 1 & $\begin{array}{l}\text { Menguran } \\
\text { gi } \\
\text { berpergia } \\
\mathrm{n} \text { dengan } \\
\text { kendaraan } \\
\text { untuk } \\
\text { tujuan } \\
\text { yang } \\
\text { dekat }\end{array}$ & $\begin{array}{l}1 \\
0\end{array}$ & $\begin{array}{l}9, \\
4\end{array}$ & 4 & $\begin{array}{l}38 \\
, 7\end{array}$ & 5 & $\begin{array}{l}47 \\
2\end{array}$ & 5 & $\begin{array}{l}4, \\
7\end{array}$ \\
\hline 1 & $\begin{array}{l}\text { Membuan } \\
\text { g sampah } \\
\text { pada } \\
\text { tempatnya }\end{array}$ & $\begin{array}{l}1 \\
5\end{array}$ & $\begin{array}{l}14 \\
, 2\end{array}$ & $\begin{array}{l}3 \\
9\end{array}$ & $\begin{array}{l}36 \\
8\end{array}$ & $\begin{array}{l}4 \\
3\end{array}$ & $\begin{array}{l}40 \\
6\end{array}$ & 9 & $\begin{array}{l}8, \\
4\end{array}$ \\
\hline
\end{tabular}


Hubungan Antara Jenis Kelamin dengan Pola pikir

Data responden yang ada dianalisis antara jenis kelamin dan pola pikir dengan menggunakan uji Chi square dengan perhitungan seperti Tabel 11

Tabel 11 Hasil perhitungan antara jenis kelamin dengan pola pikir

\begin{tabular}{|c|c|c|c|c|}
\hline \multirow[t]{2}{*}{ I } & & \multicolumn{2}{|c|}{ Pola pikir } & \\
\hline & & - & + & \\
\hline \multirow{4}{*}{ 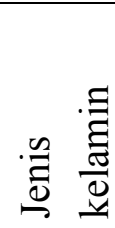 } & $\mathrm{L}$ & 7 & 20 & 27 \\
\hline & $\mathrm{P}$ & 39 & 40 & 79 \\
\hline & & 46 & 60 & 106 \\
\hline & & & $\mathrm{X}^{2}$ & 57,14 \\
\hline
\end{tabular}

\section{Hipotesis}

H0: Tidak ada hubungan antara jenis kelamin dengan pola pikir $\mathrm{H} 1$ : Terdapat hubungan antara Jenis kelamin dengan pola pikir.

\section{Tingkat Signifikansi}

Tingkat signifikansi yang digunakan adalah 5\% $(0,05) \mathrm{df}=1$ dengan nilai X2 Tabel $(\mathrm{X} 2 \mathrm{~T})=3,84$. Dengan kriteria pengujian; $\mathrm{H} 0$ diterima apabila nilai $\mathrm{X} 2 \leq 3,84$, H0 ditolak apabila nilai X2 $>3,84$

\section{Nilai X2 Hitung}

Dari tabel di atas didapat nilai $\mathrm{X} 2 \mathrm{H}=$ 57,14 dan $\mathrm{X} 2 \mathrm{H} \leq \mathrm{X} 2 \mathrm{~T}$ yang berarti $\mathrm{H} 0$ ditolak, dengan demikian ada hubungan antara jenis kelamin dengan Pengetahuan. Perbedaan jenis kelamin menunjukan perbedaan pola pikir lingkungan dan tampak bahwa mahasiswa dengan jenis kelamin lakilaki cenderung memiliki hubungan yang positif dengan pola pikir. Hal ini dapat terjadi karena, mahasiswa laki-laki lebih mempunyai kesempatan belajar dan menyerap polapikir. Walaupun pada dasarnya hal ini tidak benar dalam banyak penelitian.

Beberapa penelitian menunjukkan tidak ada hubungan antara jenis kelamin dengan pola pikir.

\section{Hubungan Antara Jenis Kelamin dengan Perilaku}

Data responden yang ada dianalisis antara jenis kelamin dan perilaku dengan menggunakan uji Chi square dengan perhitungan seperti Tabel 12.

Tabel 12 Hasil perhitungan antara jenis kelamin dengan perilaku lingkungan

\begin{tabular}{|c|c|c|c|c|}
\hline \multirow{2}{*}{\multicolumn{2}{|c|}{ II }} & \multicolumn{2}{|c|}{ Perilaku } & \\
\hline & & - & + & \\
\hline \multirow{4}{*}{. } & $\mathrm{L}$ & 2 & 25 & 27 \\
\hline & $\mathrm{P}$ & 2 & 77 & 79 \\
\hline & & 4 & 102 & 106 \\
\hline & & & $\overline{X^{2}}$ & 1,72 \\
\hline
\end{tabular}

\section{Hipotesis}

H0: Tidak ada hubungan antara jenis kelamin dengan perilaku . H1: Terdapat hubungan antara jenis kelamin dengan perilaku

\section{Tingkat Signifikansi}

Tingkat signifikansi yang digunakan adalah $5 \%(0,05) \mathrm{df}=1$, dengan nilai $\mathrm{X} 2$ Tabel $(\mathrm{X} 2 \mathrm{~T})=3,84$. Dengan kriteria pengujian; H0 diterima apabila nilai X2 $\leq$ $3,84, \mathrm{H} 0$ ditolak apabila nilai X2 $>3,8$. tabel di atas didapat nilai $\mathrm{X} 2 \mathrm{H}=1,72$ dan $\mathrm{X} 2 \mathrm{H} \leq \mathrm{X} 2 \mathrm{~T}$ yang berarti $\mathrm{H} 0$ diterima. 
Dengan demikian tidak ada hubungan antara jenis kelamin dengan sikap dari mahasiswa.

\section{Hubungan Antara Jenis Kelamin dengan Kepedulian}

Data responden yang ada dianalisis antara jenis kelamin dan kepedulian dengan menggunakan uji Chi square dengan perhitungan seperti Tabel 13.

Tabel 13 Hasil perhitungan antara jenis kelamin dengan kepedulian

\begin{tabular}{|c|c|c|c|c|}
\hline \multirow{2}{*}{\multicolumn{2}{|c|}{ III }} & \multicolumn{2}{|c|}{ Kepedulian } & \\
\hline & & - & + & \\
\hline \multirow{4}{*}{ 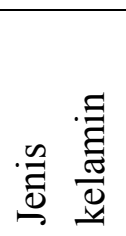 } & $\bar{L}$ & 12 & 15 & 27 \\
\hline & $P$ & 30 & 49 & 79 \\
\hline & & 42 & 64 & 106 \\
\hline & & & $\mathrm{X}^{2}$ & 1,72 \\
\hline
\end{tabular}

\section{Hipotesis}

H0 : Tidak ada hubungan antara jenis kelamin dengan kepedulian. H1 : Terdapat hubungan antara jenis kelamin dengan kepedulian.

\section{Tingkat Signifikansi}

Tingkat signifikansi yang digunakan adalah 5\% $(0,05) \mathrm{df}=1$, dengan nilai $\mathrm{X} 2$ Tabel $(\mathrm{X} 2 \mathrm{~T})=3,84$. Dengan kriteria pengujian; H0 diterima apabila nilai X2 $\leq$ 3,84 , H0 ditolak apabila nilai X2 $>3,84$

\section{Nilai X2 Hitung}

Dari tabel di atas didapat nilai $\mathrm{X} 2 \mathrm{H}=$ 1,32 dan $\mathrm{X} 2 \mathrm{H} \leq \mathrm{X} 2 \mathrm{~T}$ yang berarti $\mathrm{H} 0$ diterima, dengan demikian tidak ada hubungan antara jenis kelamin dengan kepedulian. Artinya tidak ada hubungan antara jenis kelamin dengan kepedulian. Baik untuk mahasiswa laki-laki maupun perempuan.

\section{Hubungan Antara Pola pikir dengan perilaku}

Data responden yang ada dianalisis antara Pola pikir dan perilaku dengan menggunakan uji Chi square dengan perhitungan seperti Tabel 13.

Tabel 13 Hasil perhitungan antara pola pikir dengan perilaku

\begin{tabular}{|c|c|c|c|c|}
\hline \multirow[t]{2}{*}{ IV } & & \multicolumn{2}{|c|}{ perilaku } & \\
\hline & & - & + & \\
\hline \multirow{4}{*}{$\begin{array}{l}0 \\
\frac{0}{0} \\
0 \\
0\end{array}$} & - & 2 & 25 & 27 \\
\hline & + & 2 & 77 & 79 \\
\hline & & 42 & 64 & 106 \\
\hline & & & $\mathrm{X}^{2}$ & 6,24 \\
\hline
\end{tabular}

\section{Hipotesis}

H0: pola pikir tidak ada hubungan dengan perilaku; H1: Terdapat hubungan antara pola pikir dengan perilaku .

\section{Tingkat Signifikansi}

Tingkat signifikansi yang digunakan adalah $5 \%(0,05) \mathrm{df}=1$, dengan nilai $\mathrm{X} 2$ Tabel $(\mathrm{X} 2 \mathrm{~T})=3,84$. Dengan kriteria pengujian; H0 diterima apabila nilai $\mathrm{X} 2 \leq$ 3,84 , H0 ditolak apabila nilai X2 $>3,84$ Nilai

\section{X2 Hitung}

Dari tabel di atas ini didapat nilai $\mathrm{X} 2 \mathrm{H}=$ 65,47 dan $\mathrm{X} 2 \mathrm{H} \leq \mathrm{X} 2 \mathrm{~T}$ yang berarti $\mathrm{H} 0$ ditolak, dengan demikian ada hubungan antara pola pikir dengan perilaku Mahasiswa Hal di atas sejalan dengan beberapa penelitian, bahwa semakin manusia memiliki pola pikir semakin manusia mampu untuk berperilaku atau mengemukakan perilaku- 
nyanya, artinya ada korelasi antara pola pikir dengan perilaku.

\section{Hubungan Antara Pola Pikir dengan Kepedulian}

Data responden yang ada dianalisis antara jenis kelamin dan kepedulian dengan menggunakan uji Chi square dengan perhitungan seperti Tabel 14.

Tabel 14 Hasil perhitungan antara pola pikir dengan perilaku

\begin{tabular}{|c|c|c|c|c|}
\hline \multirow[t]{2}{*}{ V } & & \multicolumn{2}{|c|}{ perilaku } & \\
\hline & & - & + & \\
\hline \multirow{4}{*}{$\begin{array}{l}\cdot \vec{z} \\
\frac{\vec{a}}{a} \\
\frac{\pi}{0} \\
0\end{array}$} & - & 12 & 15 & 27 \\
\hline & + & 27 & 52 & 79 \\
\hline & & 39 & 67 & 106 \\
\hline & & & $\mathrm{X}^{2}$ & 27,60 \\
\hline
\end{tabular}

\section{Hipotesis}

H0 : Tidak ada hubungan antara pola pikir dengan kepedulian. H1 : Terdapat hubungan antara pola pikir dengan kepedulian

\section{Tingkat Signifikansi}

Tingkat signifikansi yang digunakan adalah $5 \%(0,05) \mathrm{df}=1$, dengan nilai $\mathrm{X} 2$ Tabel $(\mathrm{X} 2 \mathrm{~T})=3,84$. Dengan kriteria pengujian; H0 diterima apabila nilai $\mathrm{X} 2 \leq$ $3,84, \mathrm{H} 0$ ditolak apabila nilai X2 >3,84

\section{Nilai X2 Hitung}

Dari tabel di atas ini didapat nilai $\mathrm{X} 2 \mathrm{H}=27,60$ dan $\mathrm{X} 2 \mathrm{H} \leq \mathrm{X} 2 \mathrm{~T}$ yang berarti H0 ditolak, dengan demikian ada hubungan variabel pola pikir dengan Kepedulian. Hasil di atas dapat dijelaskan, bahwa mahasiswa yang kuliah mempunyai pengetahuan positif mempunyai kepedulian yang positif pula.
Proses mahasiswa dari tahu kemudian menjadi peduli membutuhkan waktu yang cukup lama, namun disini terlihat, bahwa ada hubungan antara pola pikir mahasiswa dengan kepedulian, hal ini di dukung oleh apa yang dikemukakan oleh Syamsudin (1977) bahwa dalam membangun pola pikir sampai pada tahap mahasiswa peduli melalui tahapan, pertama pada tahap mahasiswa sadar, kedua tahap minat, ketiga tahap penilaian, keempat tahap mencoba dan yang kelima tahap adopsi, pada tahap terkhir ini, mahasiswa sudah mulai untuk mempraktekkan hal-hal yang diketahuinya dengan keyakinan, melakukan tindakan dalam bentuk peduli.

\section{SIMPULAN DAN SARAN}

\section{Simpulan}

Dari analisis dan pembahasan yang telah dilakukan, diperoleh kesimpulan bahwa:

Pola pikir, perilaku dan kepedulian mahasiswa Pendidikan Fisika FKIP Universitas Riau terhadap lingkungan hidup di kampus FKIP Universitas Riau, sebagai berikut:

1) Sebagian besar responden atau 50\%$58 \%$ jumlah responden memiliki nilai yang baik terhadap pola pikir tentang lingkungan hidup.

2) Ada 53\%-65\% responden menyadari bahwa perilaku salah dalam upaya menjaga kualitas lingkungan hidup di kampus FKIP Universitas Riau .

3) Kepedulian terhadap lingkungan hidup masih rendah, ini terbukti dari jawaban responden terhadap instrumen kepedulian, di mana jawaban jarang terlibat (JT) adalah jawaban 
yang paling banyak di jawab (40\%$53 \%)$

Hasil uji hubungan antara variabel jenis kelamin, mahasiswa pendidikan fisika FKIP Universitas Riau dengan pola pikir, perilaku dan kepeduliannya terhadap lingkungan hidup di Kampus Fkip Universitas Riau diperoleh kesimpulan bahwa:

1) Jenis kelamin tidak berhubungan dengan perilaku, jenis kelamin berhubungan dengan pola pikir tentang lingkungan hidup dan jenis kelamin tidak berhubungan dengan kepedulian terhadap kualitas lingku-ngan di kampus FKIP Universitas Riau .

2) Pola pikir berhubungan dengan perilaku mahasiswa pendidikan fisika, Pola pikir juga berhubungan dengan kepedulian terhadap kualitas lingkungan hidup di kampus FKIP Universitas Riau

\section{Saran-saran}

Berdasarkan kesimpulan di atas maka dapat disarankan beberapa hal, yaitu:

a. Civitas Akademika FKIP Universitas Riau yang yang juga berfungsi mengelola lingkungan hidup, mengefektifkan sosialisasi dan kampanye mengenai fungsi lingkungan hidup bagi kehidupan manusia, bagaimana meningkatkan kualitas lingkungan hidup yang di dalamnya ada sumberdaya alam, mempromosikan lingkungan sehat bagi seluruh komponen kampus.

b. Pendidikan tentang lingkungan hidup khususnya pada mata kuliah Pendidikan lingkungan sesungguhnya tidak hanya mendapatkan nilai baikk saja yang dapat menjadi panutan dan beretika di dalam lingkungan kampus tempat dimana mahasiswa menimba ilmu . Untuk itu, diharapkan bahwa pendidikan lingkungan hidup harus lebih banyak memahami masalah sosial, filsafat serta etika lingkungan hidup.

c. pengelolaan lingkungan dengan sungguh-sungguh sehingga sumberdaya alam dan lingkungan yang dimiliki oleh Indonesia khususnya dan dunia pada umumnya dapat benar-benar dipelihara dengan baik demi kehidupan manusia.

d. Perlu dilakukan penelitian lanjutan tentang jenis kelamin mana yang lebih peduli terhadap lingkungan serta yang memiliki pengetahuan yang lebih baik tentang lingkungan hidup. Dan perlu dikaji lebih lanjut, faktor-faktor apa sajakah yang mempengaruhi perbedaan tersebut.

\section{DAFTAR PUSTAKA}

Allport, G.W. 1954. Hand Book of Social Psychology. Cambridge:AddisonWesley Publishing Company. Inc

Asari, 2001. Pengetahuan, Sikap, dan Kepedulian Terhadap Lingkungan Hidup (Studi Kasus: Perbedaan antara Siswa Pramuka dengan Siswa bukan Pramuka pada Lima SLTP Negeri Jakarta Timur. Tesis Program Studi Ilmu Lingkungan Program Pascasarjana Ilmu Lingkungan Universitas Indonesia

Bonnes, M and G. Secchiaroli. 1995. Environmental Psychology A 
Psycho-Social Introduction. Sage Publications. London

Dayakisni T. dan Hudaniah. 2001. Psikologi Sosial. Penerbit UMM Malang

Djarwanto, 1989. Statistik Nonparametrik Penerbit BPFE Yogyakarta

Krech, D. 1962. Teori-teori Dasar Tentang Tingkah Laku Sosial. Terjemahan oleh Wahjoedi. Penyelenggaraan Pendidikan Pasca sarjana, Proyek Peningkatan Perguruan Tinggi. IKIP Malang.

Kumurur A. Veronika, Pengetahuan, Sikap dan Kepedulian Mahasiswa Pasca Sarjana Ilmu Lingkungan Terhadap Lingkungan Hidup Kota Jakarta, Ekoton, Vol : 8 Oktober 2008

Sarlito Wirawan Sarwono. 1992. Psikologi Lingkungan. PT. Gramedia Widiasarana Indonesia. Jakarta
Syamsudin, S, 1977. Dasar-Dasar Penyuluhan dan Modernisasi Pertanian, Penerbit Binacipta

Von Glasersfeld, E. 1996. Introduction: Aspects of Constructivism (in) C. Coscot (Ed.), Constructivism: Theory, Perspectives, and Practice. New York: Longman.

Wawolumaja, C. 2001. Instrumentasi Penelitian Kedokteran/Kesehatan dan Perilaku. Seri Nomor 3. Universitas Indonesia. Jakarta

Wawolumaja, C. 2001. Survey Epidemiologi Sederhana Bidang Perilaku Kedokteran/Kesehatan Seri Nomor 1. Universitas Indones 